\title{
Editorial
}

\section{Dilemmas about public policies and democracy in Brazil}

\section{Marco Antonio Carvalho Teixeira ${ }^{1}$}

1 Fundação Getulio Vargas / Graduate Program in Public Administration and Government, São Paulo / SP - Brazil

The recent social and political dilemmas in Brazil challenge the state's roles and relationship with society and the market. Everything seems to be in constant change, somewhat drifting, with no medium or long-term goals, only reactions to whatever happens. This scenario has been considered normal, and its consequences, which have not been assessed, affect all social segments, especially the most vulnerable groups whose living conditions only get worse.

Thus, Brazil is going through an unprecedented economic crisis. The long-term problems, the various possible causes, and the lack of solutions lead to an inevitable question: can we treat this set of problems as the expression of cyclical crisis? Apparently, no. We have increasingly naturalized some of our problems, considering them as structural challenges of society. The dissemination of collective dissensions reached a point where they are no longer just opinion polarization, aggravating social tensions. The ability to build dialogues regardless of differences to seek possible public solutions seems to be increasingly difficult. The fragmentation of divergent viewpoints is impressively high, causing a variety of social conflicts and hampering the dialogue, even among groups with similar opinions and that fought together for many causes.

As for the maintenance of the basic principles that have guided our civilization throughout history, we are witnessing a society adrift. Citizens and government authorities have openly expressed prejudice of class, race, and gender, without a significant reaction from institutions or society as a whole to cause enough social constraint to inhibit such behavior. In recent discussions at the UN Human Rights Council, Brazil aligned with Islamic countries such as Pakistan and Indonesia in an attempt to defuse the resolution on women's rights, by proposing to remove references on reproductive rights and sexual health.

It is also possible to observe a decrease in the degree of social solidarity toward the most vulnerable groups. Brazilian social solidarity has been a characteristic of the country that stood out in the past few years, supporting the country's advancement in social policies aimed at street boys and girls, the homeless population, and many other socially excluded groups for reasons of sex, race, and age.

For example, although indigenous and quilombola communities have attracted the attention of different segments of society to conquest and guarantee rights since the Brazilian Constitution of 1988 , it is frightening to witness the magnitude of social risk they currently submitted to. Despite the legal guarantees, social solidarity has not been enough to prevent the violation of their lands and threats to their lives, perpetrated by actors whose interests were previously managed by authorities. 
In the past, these groups relied on protection policies that governments promptly and continuously implemented. Today, these populations often have to fight for their rights in court, obtaining judicial decisions that may arrive too late to prevent the violations.

A similar situation can be seen with the programs and policies of affirmative action and those designed to tackle gender-based violence, child labor, and poor work conditions (Cohn, 2020). The reach of these policies was drastically reduced, supported by a narrative of meritocracy. There is some sort of social reaction and is insufficient to stop the dismantling of initiatives carried out by previous governments with different ideological perspectives, whose policies once led Brazil to be considered a global showcase of best practices in these matters. The practices of a recent past, when the dialogue involving production based on land exploitation and the necessary environmental protection resulted in goals and pacts in the public arena that became public policies. Today, the difficulties around establishing these dialogues are reflected in the upsurge of fires in the Legal Amazon for the expansion of livestock, agriculture, mining, and infrastructure projects, affecting both unprotected and, increasingly, protected land. The result is annual deforestation of more than $10,000 \mathrm{~km}^{2}$ in areas of the Amazon and Cerrado forests, environmental disasters in the region of Pantanal (fires to clear pastures), and the technological disasters caused by mining activity (Ferrante \& Fearnside, 2020).

The construction of a regulatory framework for the environment reflecting all of society's interests in a balanced way is a challenge, considering the lack of coordinated action by the federal and state governments together with academia and civil society organizations. This lack of coordination is at the core of the disorganization of the Ministry of the Environment (MMA), the Brazilian Institute of Environment and Renewable Natural Resources (Ibama), the Chico Mendes Institute for Biodiversity Conservation (ICMBio), the National Environment Council (Conama). It is also the reason for transferring some of the Ministry of Environment's competencies to the Council of the Amazon, which may be considered a form of militarization of the implementation of environmental policies, some of which were built decades ago, even before the period of re-democratization in Brazil. This situation has short-term and local consequences in the North and Central-west regions and affects the quality of water, air, and the climate in the Southeast and South of Brazil.

The Brazilian political crisis is also intense and very damaging to public debate, collective action, and public policies. Each election reveals the reduction of the ideological and programmatic dimension of political parties (Carreirão, 2014), and their difficulty to play a leading role in the political competition based on the government program. Parties are losing their power as collective actors who should organize the public debate, systematize social demands, and connect state and society, pressuring for governmental responses. Notwithstanding, the strengthening of charismatic leaders whose opinions and ideas gain the strength of a party project is frequently observed. Therefore, projects that should be collective and express the debates among party members and supporters end up reflecting the will and commitment of party leaders and their minions. It is a tendency of party oligarchization (Robert Michels, 1982), which occurs when party actions reflect the interests of the leaders much more than the social group they aim to represent. The dependence of the Brazilian Workers' Party (PT) on former president Lula da Silva, the sudden emergence of São Paulo's governor João Dória - who is steering the agenda of the Brazilian Social Democracy Party (PSDB) according to his own political interests -, and the current development 
of Bolsonarismo, are some of the most recent examples of the strength of charismatic leaders. The history of Brazil since the period known as Estado Novo has offered many examples of strong personalism.

So, how does the crisis of party representation affect public policy and government action? This occurs in different ways, from the absence of a solid government program to be debated during the electoral campaign, to the party's low capacity to discuss public issues during the mandates, both when they are incumbent or the opposition. Thus, there is an absence of projects to face the problems observed in any government transition, even when the transition between mandates occurs within the incumbent party alliance.

In Brazil, parties are collective actors who have a monopoly on candidacies. It is mandatory for candidates to be members of registered political parties, responsible for selecting a list of candidates running in every election. Therefore, political parties are directly responsible for the quality of politics and politicians. When failing in fulfilling this role, parties weaken the public debate and the decision-making processes. Thus, the less dialogue between parties and politics, and society, the lower the number of actors and interests represented in public decisions, increasing exclusion.

Such an immense crisis affecting all public and private life segments is also a reflection of a political crisis and a low capacity to include the various social interests in public decisions, especially the interests of the most vulnerable populations. Thus, engaging in politics is the best way to get out of the political crisis. It is essential to consolidate democracy by including more people in decision-making processes.

Finally, from the point of view of management and public policies, we thought we had achieved a stage of transition from populist to programmatic public policies. However, the recent developments indicate a setback, and Brazil is experiencing limbo, where policies are not completely populist or programmatic. It is a peculiar situation regarding the meaning of management and public policies, the consequence of paralysis and anachronism in the current political decision-making process. The issues presented here - which have been neglected in some of the current public policies - challenge the academic research and production of knowledge concerned with positive transformation of reality. We are facing the task of reiterating what was taken granted in terms of civility: a modern society is one that guarantees diversity, combats social exclusion, and is always looking to democratize its relations and decision-making process. Public debate has never been more necessary. Perhaps we live in a time when the simplest and inevitable way to build a better reality to improve social life is to talk, to negotiate, and, in short, engage in politics. 


\section{REFERENCES}

Carreirão, Y. S. (2014). O sistema partidário brasileiro: um debate com a literatura recente. Revista Brasileira de Ciência Política, 14, 255-295. Retrieved from https://dx.doi.org/10.1590/0103-335220141410

Cohn, A. (2020). As políticas de abate social no Brasil contemporâneo. Lua Nova: Revista de Cultura e Política, 109, 129-160. Retrieved from https://doi. org/10.1590/0102-129160/109

Ferrante, L., \& Fearnside, P. M. (2020). The Amazon's road to deforestation. Science, 369(6504), 634. Retrieved from https://doi.org/10.1126/science.abd6977

Michels, R. (1982). Sociologia dos partidos politicos. Brasília, DF: Editora UnB.

\section{Marco Antonio Carvalho Teixeira}

https://orcid.org/0000-0003-3298-8183

Ph.D. in Social Sciences from the Pontifical Catholic University of São Paulo (PUC-SP); Adjunct Professor and researcher at the Department of Public Management of Fundação Getulio Vargas' São Paulo School of Business Administration (FGV EAESP). E-mail: marco.teixeira@fgv.br 